\title{
A common definition should be used in future studies of NSC
}

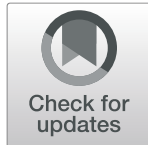

\author{
Kirsi Kemp ${ }^{1 *}$ (D, Reija Mertanen ${ }^{1}$, Leila Niemi-Murola ${ }^{2}$, Lasse Lehtonen ${ }^{3}$ and Maaret Castrén ${ }^{1}$
}

Dear Editor,

We have read with great interest a recent commentary, "How should nonspecific complaints be defined? Comment to: "nonspecific complaints (NSCs) in the emergency department" [1] concerning our systematic review [2].

In the commentary, our decision not to include studies by the BANC group was questioned. As the BANC group has laid a solid groundwork for the study of NSC, we have cited the BANC group studies throughout our review, starting with the definition of NSC. As the concept as defined by Nemec et al. is relatively new [3] and many authors have used different names for the condition (for example Djärv et al. [4]), we extended the search terms and included studies beyond this definition. Indeed, the BANC group itself suggests that the presentation of generalized weakness should be subsumed to NSC [5].

The BANC group is referring to their original definition of NSC excluding patients in triage categories 1,4 and 5. Triage for the older adults is challenging, and especially challenging when there is a lack of a specific complaint [6]. In our opinion, if a patient without a specific complaint was occasionally triaged into these excluded categories, they would still be presenting with an NSC.

In our article, we have stated the exclusion criterion of many studies from the BANC group being the patient selection in only two out of five triage categories. However, this was merely the shared attribute in the BANC group studies, and we regret having expressed the exclusion criteria poorly. Detailed reasons for exclusion of potentially relevant studies can be inspected in Appendices 2 and 3 of our review.

\footnotetext{
* Correspondence: kirsi.kemp@hus.fi

${ }^{1}$ Department of Emergency Medicine and Services, Helsinki University Hospital, and Emergency Medicine, Helsinki University, Helsinki, Finland Full list of author information is available at the end of the article
}

Not many studies have been published on NSC, and even those are heterogenous. This is reflected in our review, which is the first of its kind. We wholeheartedly agree with the BANC group, that studies on this topic should be based on a common definition to improve the quality of future reviews.

\section{Acknowledgements \\ N/A \\ Authors' contributions \\ All authors read and approved the final manuscript.}

\section{Funding}

N/A

\section{Availability of data and materials}

N/A

\section{Ethics approval and consent to participate}

$\mathrm{N} / \mathrm{A}$

\section{Consent for publication}

N/A

\section{Competing interests}

N/A

\section{Author details}

${ }^{1}$ Department of Emergency Medicine and Services, Helsinki University Hospital, and Emergency Medicine, Helsinki University, Helsinki, Finland. ${ }^{2}$ Department of Anesthesiology and Intensive Care Medicine, University of Helsinki and Helsinki University Hospital, Helsinki, Finland. ${ }^{3}$ Department of Public Health, University of Helsinki and Helsinki University Hospital, Helsinki, Finland.

Received: 15 January 2021 Accepted: 5 February 2021

Published online: 16 February 2021

\section{References}

1. Bingisser R, Nickel $\mathrm{CH}$. How should nonspecific complaints be defined? Comment to: "nonspecific complaints (NSCs) in the emergency department". Scand J Trauma Resusc Emerg Med. 2020;28(1):110.

2. Kemp K, Mertanen R, Lääperi M, Niemi-Murola L, Lehtonen L, Castren M. Nonspecific complaints in the emergency department - a systematic review. Scand J Trauma Resusc Emerg Med. 2020;28(1):6. 
3. Nemec M, Koller MT, Nickel CH, Maile S, Winterhalder C, Karrer C, et al Patients presenting to the emergency department with non-specific complaints: the Basel non-specific complaints (BANC) study. Acad Emerg Med [Internet]. 2010;17(3):284-92.

4. Castren M, Kurland L, Liljegard S, Djarv T. Non-specific complaints in the ambulance; predisposing structural factors. BMC Emerg Med. 2015;15:8.

5. Nickel CH, Malinovska A, Bingisser R. Should weakness be subsumed to nonspecific complaints?-correspondence inresponse to Bhalla et al. Am J Emerg Med. 2015;33(5):722-3.

6. Platts-Mills TF, Travers D, Biese K, McCall B, Kizer S, LaMantia M, et al. Accuracy of the emergency severity index triage instrument for identifying elder emergency department patients receiving an immediate life-saving intervention. Acad Emerg Med Off J Soc Acad Emerg Med. 2010;17(3):238-43.

\section{Publisher's Note}

Springer Nature remains neutral with regard to jurisdictional claims in published maps and institutional affiliations.

Ready to submit your research? Choose BMC and benefit from:

- fast, convenient online submission

- thorough peer review by experienced researchers in your field

- rapid publication on acceptance

- support for research data, including large and complex data types

- gold Open Access which fosters wider collaboration and increased citations

- maximum visibility for your research: over $100 \mathrm{M}$ website views per year

At BMC, research is always in progress.

Learn more biomedcentral.com/submissions 